\title{
Assessment of the acute toxicity of eutrophic sediments after the addition of calcium nitrate (Ibirité reservoir, Minas Gerais-SE Brazil): initial laboratory experiments
}

\author{
Janke, H. ${ }^{a *}$, Yamada, TM. ${ }^{a}$, Beraldo, DAS. ${ }^{a}$, Botta, CMR. ${ }^{b}$, \\ Nascimento, MRL. ${ }^{c}$ and Mozeto, AA. ${ }^{a}$ \\ áLaboratório de Biogeoquímica Ambiental, Núcleo de Estudos, Diagnósticos e Intervenções Ambientais, \\ Departamento de Química, Universidade Federal de São Carlos - UFSCar, \\ Rod. Washington Luís, Km 235, CP 676, CEP 13565-905, São Carlos, SP, Brazil \\ 'Laboratório de Ecotoxicologia, CRHEA, Universidade de São Paulo - USP, São Carlos, SP, Brazil \\ 'Laboratório de Poços de Caldas, Comissão Nacional de Energia Nuclear - CNEN, Poços de Caldas, MG, Brazil \\ *e-mail: helenajanke@uol.com.br \\ Received August 9, 2010 - Accepted October 29, 2010 - Distributed November 30, 2011
}

(With 5 figures)

\begin{abstract}
This study evaluated the acute toxicity of sediment in a eutrophic reservoir after remediation with a calcium nitrate solution to retain phosphorus. The study involved microcosms of surface sediments and water from the sedimentwater interface in the Ibirité reservoir. This reservoir, located in the vicinity of metropolitan Belo Horizonte (Minas Gerais, SE Brazil), is a water body that receives treated effluents from an oil refinery (REGAP-Petrobras), as well as high loads of untreated urban effluents from the city of Ibirité and surrounding areas and industrial effluents from a major industrial park. Incubation times of the treatment experiments were: $t=0, t=5, t=10, t=25, t=50, t=85$ and $\mathrm{t}=135$ days. One control microcosm and three treated microcosms were analysed in each time interval. Acute toxicity of water samples was assessed with Ceriodaphnia silvestrii Daday, 1902 and that of bulk sediment samples with Chironomus xanthus Rempel, 1939. Toxicity tests were carried out concomitantly with chemical analyses of dissolved inorganic nitrogen species (ammonia, nitrate and nitrite), sulfate and metals in the water samples of the microcosms. Acid volatile sulfides (AVS), simultaneously extracted metal (SEM) and potentially bioavailable metal were analyzed in bulk sediment samples. Neither of the tested organisms showed toxicity in the control microcosm samples. The water column of the treated microcosm showed toxicity to $C$. silvestrii, starting at $\mathrm{t}=10$ days, while the sediment pore water toxicity started at $t=0$ day. However, toxicity was found to decline from $t=85$ days to $t=135$ days. Sediments showed toxicity to $C$. xanthus during the entire experiment, except at the longest incubation time $(\mathrm{t}=135$ days). The overall results indicate that nitrate, which reached concentrations exceeding $1,200 \mathrm{mg} \mathrm{N}-\mathrm{NO}_{3}^{-} \mathrm{L}^{-1}$ in the sediment pore water of the treated microcosms, was most probably responsible for the toxicity of the samples. Although the calcium nitrate technology proved effective in retaining phosphorus, promoting sediment oxidation via denitrification, from the ecotoxicological standpoint and under the experimental conditions of this study, the application of nitrate for remediation of the sediments in the Ibirité reservoir did not prove effective up to a period of 135 days of incubation. However, we presume that after longer periods of incubation, treated sediments may recover their ability to sustain a benthic community. More advanced experiments are planned involving longer incubation times, thus extending the denitrification process, which may lead to a higher phosphorus retention capacity and to more complete abatement of sediment toxicity.
\end{abstract}

Keywords: sediment treatment, calcium nitrate, acute toxicity, Ceriodaphnia silvestrii, Chironomus xanthus.

\section{Toxicidade aguda de sedimentos eutrofizados (Represa Ibirité, Minas Gerais-SE, Brasil) após adição de nitrato de cálcio: experimentos iniciais de laboratório}

\footnotetext{
Resumo

O presente trabalho visou à avaliação da toxicidade aguda da aplicação de solução de nitrato de cálcio, como procedimento para remediação dos sedimentos de um reservatório eutrofizado com vistas à retenção de fósforo. $\mathrm{O}$ estudo foi realizado através de microcosmos com sedimento e amostras de interface sedimento-água da Represa Ibirité. A represa, situada na região metropolitana de Belo Horizonte (Minas Gerais, Brasil), é corpo receptor de efluentes tratados de refinaria de petróleo (REGAP-Petrobras), de altas cargas de esgoto sanitário não tratado da cidade de Ibirité e áreas vizinhas, e de efluentes industriais de importante parque industrial. Os tempos de incubação dos experimentos foram: $t=0, t=5$;
} 
$\mathrm{t}=10 ; \mathrm{t}=25 ; \mathrm{t}=50 ; \mathrm{t}=85 ; \mathrm{e} \mathrm{t}=135$ dias. Em cada um deles, foram analisadas amostras de um microcosmo-controle e três microcosmos-tratamento. A Ceriodaphnia silvestrii Daday, 1902 foi o organismo utilizado para avaliação da toxicidade aguda das amostras de água, enquanto que o Chironomus xanthus Rempel, 1939 foi empregado para a avaliação do sedimento integral. Paralelamente aos testes de toxicidade, foram realizadas análises químicas da série nitrogenada (amônia, nitrato e nitrito), sulfato, e metais nas amostras de água. Nos sedimentos foram analisados os sulfetos volatilizáveis por acidificação (SVA), metais extraídos simultaneamente (MES) e metais potencialmente biodisponíveis. Tanto as amostras de água como dos sedimentos totais dos microcosmos-controle não se mostraram tóxicos aos organismos testados. As amostras de água de interface sedimento-água dos micorocosmos-tratamento foram tóxicas para a $C$. silvestrii desde o tempo $\mathrm{t}=10$ dias e as amostras de águas intersticiais, desde o período $\mathrm{t}=0$. No entanto, foi notada uma diminuição da toxicidade do tempo $t=85$ para $t=135$ dias. Para o organismo C. xanthus, os sedimentos em tratamento se mostraram tóxicos durante todo o experimento, exceto no tempo $t=135$ dias. Os

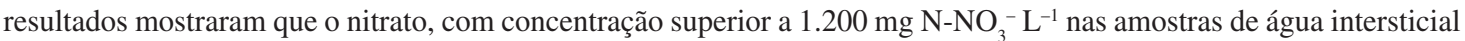
dos sedimentos dos microcosmos-tratamentos, é a causa mais provável da toxicidade das amostras. Embora a tecnologia de adição de nitrato tenha se mostrado eficaz na retenção de fósforo nos sedimentos, pois causa a oxidação dos sedimentos através do incremento substancialmente da taxa de desnitrificaçao, do ponto de vista ecotoxicológico e para as condições experimentais deste trabalho, a aplicação do nitrato como forma de intervenção para remediação dos sedimentos da Represa Ibirité não se mostrou adequada até o período de 135 dias. Após este período, presume-se que os sedimentos tratados possam recuperar a capacidade de sustentar uma comunidade bentônica. Experimentos mais avançados foram planejados, visando um tempo de incubação mais estendido, que, por conseguinte, pode levar a uma maior capacidade de retenção de $\mathrm{P}$ e ao abatimento total da toxicidade dos sedimentos e da água, devido a um maior avanço do processo da desnitrificação.

Palavras-chave: tratamento de sedimentos, nitrato de cálcio, toxicidade aguda, Ceriodaphnia silvestrii, Chironomus xanthus.

\section{Introduction}

The artificial eutrophication of lakes and urban reservoirs is the result of intensive discharge of domestic and industrial effluents and has become one of the biggest threats to continental waters (Tundisi et al., 2008). Numerous efforts have focused on solving this problem by controlling the input of nutrients to aquatic environments, especially of phosphorus. However, despite the mitigation of external sources, sediments in eutrophic water bodies can continue to act as sources of nutrients to the water column, causing internal fertilisation (Vaccari et al., 2006).

Using this approach, Ripl (1976) developed a pioneering study to retain phosphorus in lake sediments by applying a solution of calcium nitrate in sediments and thereby suppressing the release of phosphorus to the water column. Since these early experiments, similar studies have provided adequate results in controlling the release of phosphorus in eutrophic water bodies, applying the same principle proposed by Ripl in 1976 (Foy, 1985; Feibicke, 1997; McAuliffe et al., 1998).

Ripl's studies took into consideration that biomass degradation in sediments in reduced environments occurs through the use of alternative electron acceptors in the respiration of facultative anaerobic bacteria (Marsden, 1989). A decrease in the sediment redox potential reduces manganese (IV) to manganese (II) and iron (III) to iron (II) which in turn causes the release of phosphorus adsorbed on Fe and Mn oxide-hydroxide particles (Schauser et al., 2006), thus increasing phosphorus concentrations in the water column.

According to the above model, it is known that alternative oxygen acceptors preferably reduced under anoxia are nitrate, manganese (IV), iron (III), and sulfate

(McAuliffe et al., 1998). Thus, there is a microbiologically mediated sequence of redox processes in sediment, from the most electropositive to the most electronegative: $\mathrm{O}_{2} /$ $\mathrm{H}_{2} \mathrm{O}>\mathrm{NO}_{3}-/ \mathrm{N}_{2}>\mathrm{MnO}_{2}(\mathrm{~s}) / \mathrm{Mn}^{+2}>\mathrm{FeOOH}(\mathrm{s}) / \mathrm{Fe}^{+2}>\mathrm{SO}_{4}^{-2} /$ $\mathrm{HS}^{-}>\mathrm{CO}_{2} / \mathrm{CH}_{4}$ (Stumm and Morgan, 1996). Following this sequence of electron acceptors, the supply of nitrate in sediment must consequently increase the action of denitrifying bacteria that use nitrate, which is less costly energetically speaking, and promotes phosphorus retention (as the orthophosphate ion) due to the oxidation of iron (II) to iron (III) oxyhydroxides.

This sediment restoration method predicts $\mathrm{CO}_{2}$ and molecular nitrogen $\left(\mathrm{N}_{2}\right)$ as final products of the reaction mediated by denitrifying bacteria. However, intermediate products such as nitrite $\left(\mathrm{NO}_{2}^{-}\right)$, nitric oxide $(\mathrm{NO})$, and nitrous oxide $\left(\mathrm{N}_{2} \mathrm{O}\right)$ can be formed in certain environmental conditions (Madigan and Martinko, 2006; Van Rijn et al., 2006).

The results that Foy obtained in his experiments (Foy, 1986) indicate that denitrification to elemental nitrogen was the dominant reaction. He used core experiments in which a solution of calcium nitrate equivalent to $6.17,15.4,30.9$ and $61.7 \mathrm{~g} \mathrm{~N} \mathrm{~m}^{-2}$ was injected into sediments. Foy predicted that a nitrate input of 30 to $60 \mathrm{~g} \mathrm{~N} \mathrm{~m}^{-2}$ was required to prevent sediment release of phosphorous. Feibicke (1997) carried out an in situ experiment in the Schkei Fjord (Western Baltic, Germany), applying a dose of $140 \mathrm{~g} \mathrm{~N} \mathrm{~m}^{-2}$, and reported a P-reduction of 66 to $70 \%$ in comparison to the reference area (where no application was made).

Although more detailed studies of this remediation process have been developed, there is little or almost no 
discussion of possible ecotoxicological consequences resulting from the addition of nitrate to sediments in aquatic environments. Pollution with high concentrations of inorganic nitrogen can promote excessive phytoplanktonic growth during denitrification in $\mathrm{N}$-limiting environments (Petzoldt and Uhlmann, 2006). Another interesting point is the possible formation of nitrite and ammonium through the excessive addition of nitrate or lack of optimal conditions for its use as an electron acceptor. High inorganic nitrogen concentrations can cause toxicity to the aquatic life in the environment (Schauser et al., 2006).

In addition to the aforementioned problems, the oxidation of metal sulfides (i.e., of AVS, which are composed mainly of iron monosulfides) favors metal availability to aquatic organisms as the AVS is oxidized to sulfate, yielding potentially toxic aqueous metal ions. According to Di Toro et al. (1990) and Allen et al. (1993), sulfides react with metal ions in anoxic sediments, such as iron (most commonly), cadmium, copper, mercury, nickel, lead, and zinc, forming extremely insoluble precipitates, controlling partition and consequent assimilation of ions from these elements. If the sulfide ion concentration exceeds the total metal concentration, all the metal ions will be immobilised as insoluble sulfides, making them unavailable for biological processes. Sulfide oxidation can therefore eliminate one of the controlling phases of availability of such elements to aquatic biota.

The aim of this study was to evaluate the acute toxicity of sediments treated with a calcium nitrate solution as a procedure for sediment remediation in the Ibirité reservoir (SE Brazil), a eutrophic aquatic environment. The experiments were performed in microcosms consisting of surface sediment and water of the sediment-water interface taken from the study area. The acute toxicity assays were performed using Ceriodaphnia silvestrii Daday, 1902 and Chironomus xanthus Rempel, 1939 for water samples (water column and sediment pore water) and bulk sediment samples, respectively, before and after the application of nitrate, in an incubation period of 135 days.

\section{Material and Methods}

\subsection{Study area}

The Ibirité reservoir is located in the metropolitan area of Belo Horizonte (Minas Gerais, SE Brazil), between the cities of Ibirité and Sarzedo (19 $07^{\circ} 00^{\prime \prime}-20^{\circ} 02^{\prime} 30^{\prime \prime} \mathrm{S}$; $\left.44^{\circ} 07^{\prime} 30^{\prime \prime}-44^{\circ} 05^{\prime} 00^{\prime} \mathrm{W}\right)$, a densely populated and heavily industrialised region. The reservoir was built in 1968 by Petrobras (Petroleo Brasileiro S/A) to serve as a water source for the industrial processes of the Gabriel Passos Refinery (REGAP). As a result of the intense development of this area, the Ibirité reservoir became the recipient not only of the refinery's treated effluents but also of heavy loads of untreated urban effluents from the city of Ibirité and surroundings and of effluents from numerous industrial plants. As a result, the reservoir became hypereutrophic, as indicated by the high concentrations of total phosphorus in the sediment and in the water column and of orthophosphate in the water column and sediment pore water (Mozeto, 2003, 2008; Mozeto et al., 2010). Intense cyanobacterial blooming has been observed throughout the year (Barbosa, 2003).

\subsection{Experimental design}

The microcosms were assembled with surface sediments and water from the sediment-water column interface, which were collected at a sampling point beside the dam's outlet in the Ibirité reservoir. The samples collected here showed relatively high concentrations of orthophosphate of $0.15 \mathrm{mg} . \mathrm{L}^{-1}$ in the water column and $0.48 \mathrm{mg} . \mathrm{L}^{-1}$ in the sediment pore water, as well as high concentrations of total phosphorus in the sediment $\left(1,445.59 \mathrm{mg} \cdot \mathrm{kg}^{-1}\right)$. The concentration of ammonia was $1.10 \mathrm{mg} . \mathrm{L}^{-1}$ in the water column and $16.00 \mathrm{mg} . \mathrm{L}^{-1}$ in the sediment pore water samples. A grain size analysis showed a high percentage (91\%) of fine particulates such as clay and silt (Mozeto, 2008).

Samples of surface sediments $(20 \mathrm{~cm}$ depth) were collected with a stainless steel Birge-Ekman dredge. Water samples from the sediment-water interface were collected using an immersion pump fed by a car battery and connected to a silicon hose. Samples were refrigerated at $4{ }^{\circ} \mathrm{C}$ until the microcosms were set up in the laboratory.

Twenty eight microcosms were set up in cylindrical glass jars $30 \mathrm{~cm}$ in height and $16 \mathrm{~cm}$ in diameter. Sediment samples were first homogenised in a plastic bucket and slowly poured into the glass jars up to a height of about $6 \mathrm{~cm}$, which amounted to about $1 \mathrm{~kg}$ of sediment $/$ microcosm. Twenty $\mathrm{mL}$ of calcium nitrate solution $\left(\mathrm{Ca}\left(\mathrm{NO}_{3}\right)_{2} \cdot 4\left(\mathrm{H}_{2} \mathrm{O}\right)\right)$ were added to 21 microcosms, corresponding to $140 \mathrm{~g} \mathrm{~N} \mathrm{~m}^{-2}$ (2,83 $\mathrm{g} \mathrm{N} /$ microcosm); this amount was determined earlier in experiments by Ripl (1976) and Foy (1985). The salt solution was injected into the first $5 \mathrm{~cm}$ of sediment using a syringe attached to a Pasteur pipette by a silicone hose. After this procedure, $4 \mathrm{~L}$ of water from the reservoir sediment-water interface were gradually added to the 28 microcosms.

The entire procedure was performed in a nitrogen gas atmosphere to minimise sediment oxidation and to mimic, as much as possible, the natural conditions of the sediment-water interface. The glass jars were closed with plastic screw lids and covered with aluminum foil to protect them against light. All the microcosm jars were kept in a temperature controlled room at approximately $20 \pm 1.0^{\circ} \mathrm{C}$ throughout the experiment.

Seven incubation times were established to open the microcosms: $t=0$, after system stabilisation (sedimentation), which occurred on the set-up day, $\mathrm{t}=5, \mathrm{t}=10, \mathrm{t}=25, \mathrm{t}=50$, $t=85$, and $t=135$ days after the microcosm experiments were set up. Four jars containing microcosms were opened each day for chemical determinations and acute toxicity assay: one control microcosm (without added nitrate) and three treated microcosms (with added nitrate).

Water samples were collected at the sediment-water interface of each microcosm (i.e., the microcosm water column) using a syringe attached to a silicone hose. 
About $200 \mathrm{~g}$ of bulk sediment were collected for acute toxicity assays. The pore water was extracted from the remaining sediment by centrifugation of $200 \mathrm{~mL}$ aliquots for 15 minutes at $3,000 \mathrm{rpm}$ and at $4{ }^{\circ} \mathrm{C}$. All the samples were refrigerated at about $4{ }^{\circ} \mathrm{C}$ until the beginning of the acute toxicity tests and chemical analyses. These procedures are described below.

\subsection{Acute toxicity assays: Ceriodaphnia silvestrii Daday, 1902}

Ceriodaphnia silvestrii Daday, 1902 (Crustacea, Cladocera, Daphnidae) is an endemic Neotropical species widely distributed throughout South America (Fonseca and Rocha 2004a). This test organism was chosen for the present study because it is a native Brazilian daphnia and is therefore a more representative species of the ecosystem, as recommended by Rand and Petrocelli (1985). Moreover, because $C$. silvestrii is as sensitive to pollutants as $C$. dubia, it is suitable as a test organism (Oliveira-Neto and BottaPaschoal 2000) and has been used in other toxicity assays (Takenaka et al., 2007).

The acute toxicity of sediment pore water and water column samples was evaluated based on tests with C. silvestrii, following ABNT (2004) procedures. These acute toxicity assays were performed with the initial samples, i.e., before set-up of the microcosms, and with samples from the microcosms at $\mathrm{t}=0, \mathrm{t}=5, \mathrm{t}=10, \mathrm{t}=50$, $\mathrm{t}=85$ and $\mathrm{t}=135$ days. Twenty individuals of $C$. silvestrii neonates $(<24$ hours old), distributed in two duplicates, were added to test samples (dilutions of the initial samples) and laboratory control (only culture water). Tests were assembled in polyethylene cups containing $10 \mathrm{~mL}$ of test medium and kept at room temperature $\left(22{ }^{\circ} \mathrm{C}\right)$, under a photoperiod of 12 hours and without feeding. The number of immobilised juveniles in each cup was recorded after 48 hours. Test results were accepted only when the mortality rate of the controls did not exceed $10 \%$. Toxicity of $C$. silvestrii samples was expressed in 48 hours LC50 values, according to the Trimmed-Spearman Karber statistical method (Hamilton et al., 1977). The volumes of interstitial water samples from the microcosms $\mathrm{t}=0$ and $t=50$ days were not sufficient for the complete realisation of the acute toxicity tests. Therefore, the 48 hours LC50 was expressed by the lowest concentration of sample tested.

\subsection{Acute toxicity assays: Chironomus xanthus Rempel, 1939}

Chironomus xanthus Rempel, 1939 (Diptera, Chironomidae) is an insect species whose geographic distribution is restricted to Argentina and Brazil (Fonseca and Rocha, 2004b). Because it is a native Brazilian species (Trivinho-Strixino and Strixino, 1982), C. xanthus is of great ecological and regional relevance and its larval stage has been used in toxicity tests with sediments in Brazil (Dornfeld et al., 2006; Sotero-Santos et al., 2007). Its sensitivity has also been adequately studied (Santos et al., 2007).
In the present study, the acute toxicity of bulk sediments was evaluated through tests with $C$. xanthus, using methods described by Fonseca (1997). These acute toxicity assays were performed on the initial samples, i.e., before set-up of the microcosms, and with samples from the $t=0, t=10$; $t=50$ and $t=135$ day microcosms. Tests were assembled in polyethylene cups containing $60 \mathrm{~g}$ of sediment samples and $240 \mathrm{~mL}$ of culture water, and were performed in triplicate. The laboratory controls were performed with sterile sand, which was first heated in a muffle furnace for 2 hours at $500{ }^{\circ} \mathrm{C}$. Six individuals of third or fourth instar C. xanthus were placed in each cup. The organisms were exposed for 96 hours, without aeration, in a 12 hours photoperiod at room temperature $\left(22^{\circ} \mathrm{C}\right)$. Test results were accepted only when the mortality rate in the laboratory control did not exceed $10 \%$. The mortality rate of organisms exposed to sediment samples was compared to that of the laboratory control at the end of exposure, using Fisher's Exact Test (with a statistical significance of $\mathrm{p}<0.05$ ) and BioStat ${ }^{\circledR}$ version 5.0 software.

\subsection{Chemical analyses}

All the analyses described below were performed in initial samples, before set-up of the microcosms, and samples from microcosms $\mathrm{t}=0 ; \mathrm{t}=5 ; \mathrm{t}=10 ; \mathrm{t}=25 ; \mathrm{t}=50$; $\mathrm{t}=85$; and $\mathrm{t}=135$.

The parameters of hydrogen-ion potential $(\mathrm{pH})$ in water samples and redox potential $\left(\mathrm{E}_{\mathrm{H}}\right)$ in sediments were measured with a portable Digimed DM-2P pH meter, using a combined DMR-CP2 platinum electrode. Data were compared by the Mann-Whitney U-test (with a statistical significance of $\mathrm{p}<0.05)$ using BioStat ${ }^{\circledR}$ version 5.0 software.

Ammonium $\left(\mathrm{NH}_{3}\right)$, nitrite $\left(\mathrm{N}_{-} \mathrm{NO}_{2}^{-}\right)$, nitrate $\left(\mathrm{N}-\mathrm{NO}_{3}^{-}\right)$ and sulfate $\left(\mathrm{SO}_{4}^{-2}\right)$ were determined in sediment pore water samples and water from sediment-water interface samples using a Hach DR/2010 portable spectrophotometer, according to the APHA method (1992). After filtration of the same samples through $0.45 \mathrm{~mm}$ cellulose acetate membranes, $\mathrm{Al}, \mathrm{Fe}, \mathrm{Mn}$, and $\mathrm{Zn}$ were also determined by inductively coupled plasma-optical emission spectrometry (ICP-OES), while $\mathrm{Cu}, \mathrm{Ni}$, and $\mathrm{Pb}$ were analysed by graphite furnace atomic absorption spectroscopy (GFAAS). The limits of quantification (LOQ) (mg.L. $\left.\mathrm{L}^{-1}\right)$ of these elements were $\mathrm{Al}$ (0.1); Cu (0.004); Ni (0.005); Fe (0.05); Mn (0.02); $\mathrm{Pb}$ (0.001); Zn (0.02) (Nascimento and Mozeto, 2008).

Potentially bioavailable metals in the sediment were determined for $\mathrm{Al}, \mathrm{Cu}, \mathrm{Fe}, \mathrm{Mn}, \mathrm{Ni}, \mathrm{Pb}$, and $\mathrm{Zn}$, according to the USEPA extraction method 3050B (USEPA, 1996), following the detection by ICP-OES. The LOQ for these elements were $\left(\mathrm{mg} \cdot \mathrm{kg}^{-1}\right)$ : $\mathrm{Al}$ (5.0), $\mathrm{Cu}$ (1.0), Fe (2.5), $\mathrm{Mn}$ (1.0), Ni (5.0), Pb (10.0) and Zn (1.0) by ICP-OES (Nascimento and Mozeto, 2008).

AVS (acid volatile sulfides) and SEM (simultaneously extracted metals) $(\mathrm{Cd}, \mathrm{Cu}, \mathrm{Ni}, \mathrm{Pb}$ and $\mathrm{Zn}$ ) analyses of the sediment samples were performed according to the methods proposed by Allen et al. (1993), using wet samples whose water content was previously determined (Silvério et al., 2006). AVS quantifications were performed with a portable 
Hach spectrophotometer, according to the APHA method (1992). The SEM Cd and $\mathrm{Pb}$ were detected via GFAAS and $\mathrm{Cu}, \mathrm{Ni}$ and $\mathrm{Zn}$ were detected by ICP-OES. The LOQ of these elements were (mg. $\left.\mathrm{kg}^{-1}\right)$ : $\mathrm{Cd}$ (0.05); $\mathrm{Cu}$ (1.0); Pg (10.0); $\mathrm{Ni}$ (5.0); and Zn (1.0) (Nascimento and Mozeto, 2008).

The difference between control microcosms and treated microcosms was evaluated by means of HAC cluster analysis (Hierarchical Agglomerative Cluster Analysis), using the Euclidean distance as a measure of dissimilarity. Analyses were carried out aided by XLStat software (version 2006.6).

All the glassware used in the assays was washed with Extran ${ }^{\circledR}$ (Merck), rinsed in acetone and methanol PA (Merck ${ }^{\circledR}$ or Synth ${ }^{\circledR}$ ) and oven-dried at $105^{\circ} \mathrm{C}$. All the reagents used for extractions were of HPLC grade and were supplied by Baker, Merck or Mallinckrodt.

\section{Results and Discussion}

The experimental results showed that the addition of nitrate increased significantly (according to the Mann-Whitney U-test) the $\mathrm{E}_{\mathrm{H}}$ of the sediments of treated microcosms, which exceeded that of the control microcosms at all the incubation times (Table 1). These $\mathrm{E}_{\mathrm{H}}$ values are a clear indication that nitrate acted as an oxidizing agent in the sediments, since the $\mathrm{E}_{\mathrm{H}}$ values of treated and control

Table 1. Measured values of redox potential $\left(\mathrm{E}_{\mathrm{H}}\right)$ of the sediments.

\begin{tabular}{cccc}
\hline \multirow{2}{*}{$\begin{array}{c}\text { Incubation time } \\
\text { (days) }\end{array}$} & \multicolumn{3}{c}{$\mathbf{E}_{\mathbf{H}}(\mathbf{m V})$} \\
\cline { 2 - 4 } Initial & Control & Treated & sd \\
\hline $\mathrm{t}=0$ & -154.0 & - & - \\
$\mathrm{t}=5$ & -124.0 & -104.7 & 2.9 \\
$\mathrm{t}=10$ & -197.0 & -46.3 & 5.5 \\
$\mathrm{t}=25$ & -163.0 & -90.0 & 1.4 \\
$\mathrm{t}=50$ & -170.0 & -49.0 & 16.5 \\
$\mathrm{t}=85$ & -174.0 & -37.0 & 14.2 \\
$\mathrm{t}=135$ & -134.0 & 138.7 & 32.7 \\
\hline
\end{tabular}

microcosms were $124.0 \mathrm{mV}$ and $-104.7 \mathrm{mV}$, respectively, at an incubation time of $\mathrm{t}=0$. This behavior, which was also reported by Murphy et al. (1995) and McAuliffe et al. (1998), remained constant up to the incubation time of $\mathrm{t}=135$ days, when the $\mathrm{E}_{\mathrm{H}}$ of the control and treated microcosms reached -134.0 and $138.7 \mathrm{mV}$, respectively.

The $\mathrm{pH}$ data indicate that there was no significant difference between control and treated microcosm throughout the incubation times of samples from the water column and from sediment pore water (considering all the values, the $\mathrm{pH}$ varied from 6 to 7.4) (Table 2).

The test organisms $C$. silvestrii and $C$. xanthus were not affected upon exposure to water samples (sediment pore water and water column) and sediments, respectively, in the initial and control microcosm samples. The sediment pore water samples of the treated microcosms were toxic to $C$. silvestrii, starting at $\mathrm{t}=0(\mathrm{LC} 50<12.5 \%)$. Toxicity increased at $\mathrm{t}=5$ days $(\mathrm{LC} 50=5.01 \%), \mathrm{t}=10$ days $(\mathrm{LC} 50=4.98 \%), \mathrm{t}=50$ days $(\mathrm{LC} 50<2.5 \%)$ and up to $\mathrm{t}=85$ days $(\mathrm{LC} 50=2.66 \%)$. A decrease in toxicity was observed at $\mathrm{t}=135$ days $(\mathrm{LC} 50=66.11 \%)$. Acute toxicity to $C$. silvestrii of water from the water column started at $\mathrm{t}=10$ days $(\mathrm{LC} 50=62.81 \%)$, increasing at $\mathrm{t}=50$ days $(\mathrm{LC} 50=20.68 \%)$ and $\mathrm{t}=85$ days $(\mathrm{LC} 50=17.19 \%)$, and decreasing at $\mathrm{t}=135$ days $(\mathrm{LC} 50=20.68 \%)$ in relation to the previous incubation time. The toxicity results for 48-h LC50 of water samples to C. silvestrii are illustrated graphically in Figure 1.

Toxicity tests with $C$. xanthus in bulk sediment samples corroborated the $C$. silvestrii data obtained from sediment pore water samples. All the organisms exposed to treated sediments died when they were tested at incubation times of $\mathrm{t}=0, \mathrm{t}=10$, and $\mathrm{t}=50$ days, but organisms exposed to sediments from treated microcosms at $\mathrm{t}=135$ days showed no significant mortality.

Based on the inorganic nitrogen compounds found in the sediment pore water (Figure 2), we postulate that the main chemical species that probably caused the elevated toxicity to $C$ silvestrii was nitrate. Nitrate concentrations reached higher values than the 48 hours LC50 of $\mathrm{N}^{-N_{3}}{ }^{-}$ reported in the literature for Ceriodaphnia dubia and Daphnia magna, which was 374 and $462 \mathrm{mg} \mathrm{N}-\mathrm{NO}_{3}{ }^{-} \mathrm{L}^{-1}$,

Table 2. $\mathrm{pH}$ values measured in the water (water column and sediment pore water) of control and treated microcosms.

\begin{tabular}{|c|c|c|c|c|c|c|}
\hline \multirow{3}{*}{$\begin{array}{l}\text { Incubation time } \\
\text { (days) }\end{array}$} & \multicolumn{6}{|c|}{ pH } \\
\hline & \multicolumn{3}{|c|}{ Water column } & \multicolumn{3}{|c|}{ Sediment pore water } \\
\hline & Control & Treated & sd & Control & Treated & sd \\
\hline Initial & 7.24 & - & - & 7.01 & - & - \\
\hline $\mathrm{t}=0$ & 7.36 & 7.35 & 0.04 & 6.87 & 6.65 & 0.14 \\
\hline$t=5$ & 6.93 & 7.04 & 0.02 & 6.81 & 6.57 & 0.07 \\
\hline $\mathrm{t}=10$ & 6.95 & 6.51 & 0.04 & 6.95 & 6.70 & 0.03 \\
\hline$t=25$ & 6.51 & 6.28 & 0.02 & 6.80 & 6.64 & 0.16 \\
\hline $\mathrm{t}=50$ & 6.68 & 6.15 & 0.01 & 6.72 & 6.83 & 0.05 \\
\hline $\mathrm{t}=85$ & 6.49 & 6.13 & 0.04 & 6.63 & 6.75 & 0.10 \\
\hline$t=135$ & 6.63 & 6.41 & 0.15 & 6.82 & 6.78 & 0.02 \\
\hline
\end{tabular}




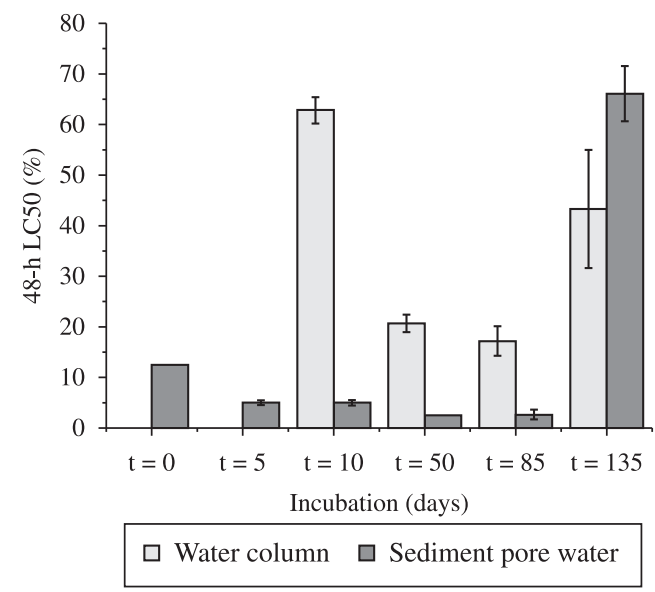

Figure 1. Values of 48 hours LC50 to $C$. silvestrii in water samples (water column and sediment pore water) of treated microcosms.
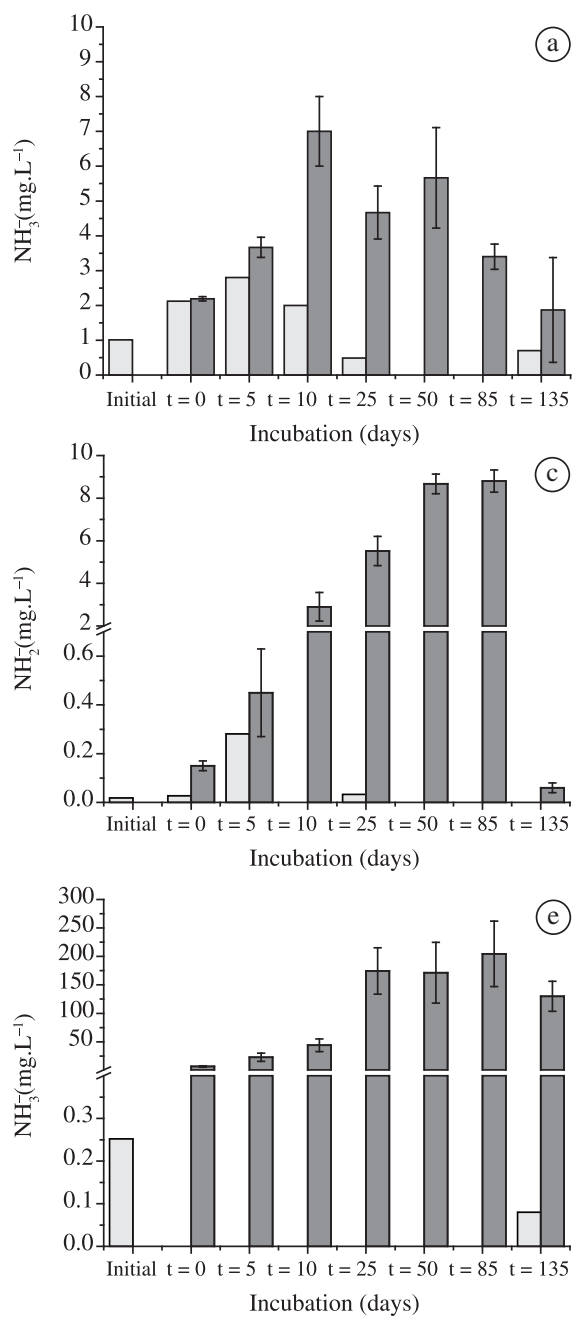

respectively (Scott and Crunkilton, 2000). The decrease in toxicity of the sediment pore water samples observed at $\mathrm{t}=135$ days in the treated microcosm was commensurate with the decrease in the nitrate concentration determined in the same samples. The nitrate concentration in water samples from the water column was lower than the aforementioned toxicity values, starting at the first incubation time $(\mathrm{t}=0)$ until the end of the experiments $(t=135$ days $)$. Considering that the toxicity of the water column was detected after the treatment time of $\mathrm{t}=10$ days, other compounds besides nitrate may have been responsible for the sample's toxicity.

The unionised ammonia concentrations (Figure 2) in water samples from the water column in treated microcosms increased up to $t=10$ days, at which point the concentrations were three-fold higher than those found in the control microcosms. This was the treatment time when acute toxicity to $C$. silvestrii began to become observable in these water samples. As a matter of fact, $\mathrm{NH}_{3}$ concentrations detected
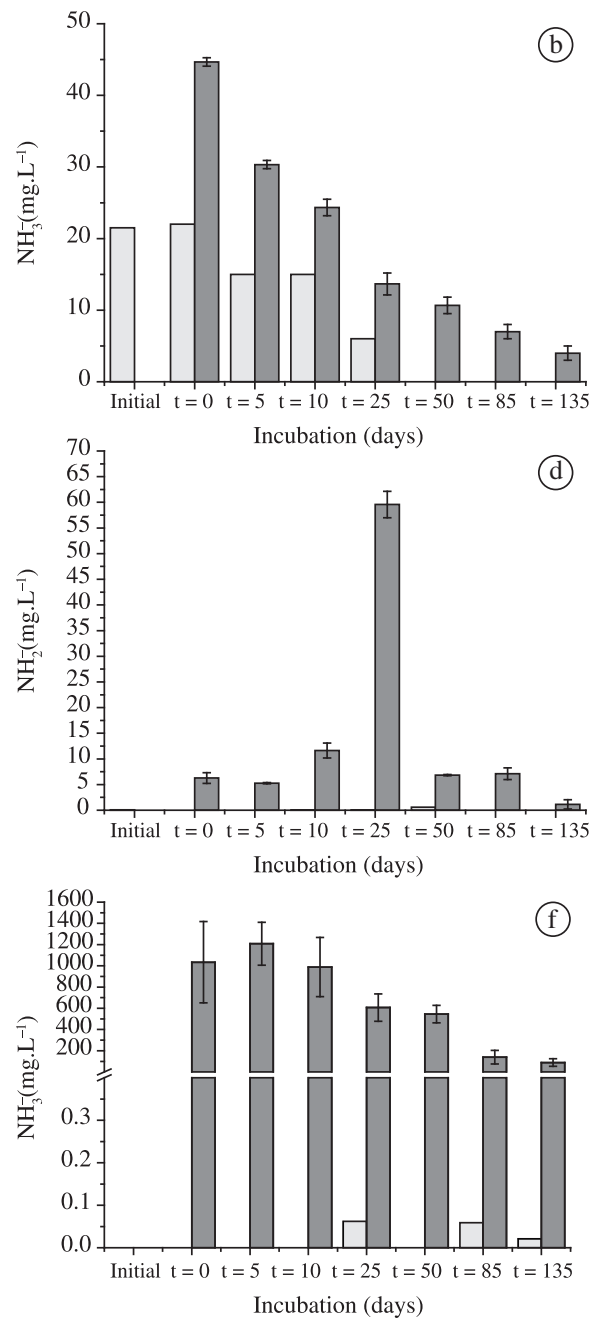

$\square$ Control $\square$ Treated

Figure 2. Concentrations of unionised ammonia $\left(\mathrm{NH}_{3}\right)$ in: a) water column, b) sediment pore water; nitrite $\left(\mathrm{N}_{-}-\mathrm{NO}_{2}^{-}\right)$in: c) water column, d) sediment pore water; nitrate $\left(\mathrm{N}_{-} \mathrm{NO}_{3}^{-}\right)$in: e) water column, f) sediment pore water. 
in water column samples at $\mathrm{t}=10$ days were higher than the 48 hours LC50 data $\left(1.18 \mathrm{mg} \mathrm{NH}_{3} \mathrm{~L}^{-1}\right)$ reported by Andersen and Buckey (1998) for C. dubia. However, at some treatment times, elevated values were also detected in water samples from the water column and sediment pore water of the control microcosm, which showed no toxicity to $C$. silvestrii. Thus, the chemical species ammonia may not have contributed to toxicity in the experimental conditions employed in this study, at least up to values less than $22 \mathrm{mg} . \mathrm{L}^{-1}$ (the highest value measured in sediment pore water that was nontoxic to $C$. silvestrii).

The measured concentrations of $\mathrm{N}_{-} \mathrm{NH}_{3}, \mathrm{~N}_{-} \mathrm{NO}_{3}^{-}$, and $\mathrm{N}-\mathrm{NO}_{2}{ }^{-}$were considerably higher than the limit values established by the water quality criteria indicated in toxicity data for aquatic organisms. Based on acute toxicity data, concentrations of $\mathrm{N}-\mathrm{NH}_{3}$ in the range of $0.05-0.35 \mathrm{mg} . \mathrm{L}^{-1}$ in continental waters are considered acceptable (USEPA 1999). Alonso (2005 apud Camargo and Alonso, 2006) recommended concentrations between $0.08-0.35 \mathrm{mg} . \mathrm{L}^{-1}$ for $\mathrm{N}_{-} \mathrm{NO}_{2}^{-}$, which is adequate for the protection of aquatic life. Camargo et al. (2005), on the other hand, proposed a maximum $\mathrm{N}_{-} \mathrm{NO}_{3}{ }^{-}$concentration of $2 \mathrm{mg} \cdot \mathrm{L}^{-1}$.

The toxicity results with $C$. xanthus using bulk sediment samples corroborated the data obtained from sediment pore water for $C$. silvestrii. Considering these results, despite the absence of reports in the literature relating dissolved inorganic nitrogen species to the toxicity of sediment pore water to C.xanthus, it can be postulated that the decrease in sediment toxicity in treated microcosms incubated for $\mathrm{t}=135$ days ( $0 \%$ mortality) may be related to the decrease observed in nitrate, nitrite and ammonia concentrations in the sediment pore water.

In addition to above described procedures, the concentrations of bioavailable metals in sediment (Table 3) were compared to the values of the sediment quality guidelines (SQG) given in Burton Junior (2002). This comparison indicated that none of the data exceeded the SQG's PEL (Probable Effect Level), which defines the concentration above which adverse biological effects frequently occur. PEL values for metals (mg. $\mathrm{kg}^{-1}$ ), according to Burton Junior op.cit., are 197 for $\mathrm{Cu}, 36$ for $\mathrm{Ni}, 91.3$ for $\mathrm{Pb}$ and 315 for $\mathrm{Zn}$. Thus, it is expected that the toxicity of sediment samples to $C$. xanthus was not caused by metals, particularly since the metal concentrations in sediment samples from treated microcosms were very similar to those of control microcosms, which were nontoxic to test organisms.

One or more chemical species other than the dissolved inorganic nitrogen species may have caused this increase in toxicity in the samples of sediment pore water and water colunm during incubation of the treated microcosms. The main suspected species in this case are sulfate and manganese, which showed increased concentrations throughout the duration of these experiments.

Metals such as iron and manganese were found in higher concentration in water samples from water column of treated microcosms than in control microcosms (Table 4). This trend was differentiated by the HAC. In the sediment pore water (Table 5), the highest concentration was nickel

Table 3. Concentration of bioavailable metal in sediment samples $\left(\mathrm{mg}^{\mathrm{kg}} \mathrm{kg}^{-1}\right)$.

\begin{tabular}{|c|c|c|c|c|c|c|c|c|c|}
\hline \multirow{2}{*}{ Metal } & \multirow{2}{*}{ Microcosm } & \multicolumn{8}{|c|}{ Period (days) } \\
\hline & & Initial & $t=0$ & $t=5$ & $t=10$ & $t=25$ & $t=50$ & $t=85$ & $t=135$ \\
\hline \multirow[t]{3}{*}{$\mathrm{Al}$} & Control & 67697.90 & 66836.45 & 67257.61 & 66556.37 & 72215.77 & 70244.79 & 64950.00 & 66450.00 \\
\hline & treated & & 70287.55 & 66537.28 & 71156.49 & 72880.09 & 68563.53 & 68600.00 & 66216.67 \\
\hline & sd & & 1658.03 & 675.24 & 3741.66 & 1192.70 & 2050.72 & 3121.30 & 2327.19 \\
\hline \multirow[t]{3}{*}{$\mathrm{Cu}$} & Control & 109.69 & 117.42 & 115.47 & 105.63 & 118.86 & 110.28 & 130.00 & 128.00 \\
\hline & treated & & 119.32 & 108.12 & 111.97 & 116.11 & 110.86 & 129.67 & 128.17 \\
\hline & sd & & 4.07 & 5.14 & 1.72 & 2.32 & 3.04 & 1.53 & 3.33 \\
\hline \multirow[t]{3}{*}{$\mathrm{Ni}$} & Control & 28.20 & 25.90 & 30.40 & 29.75 & 31.80 & 29.70 & 29.20 & 27.90 \\
\hline & treated & & 25.90 & 28.00 & 27.45 & 33.05 & 30.15 & 29.72 & 30.57 \\
\hline & sd & & 1.10 & 3.50 & 0.05 & 1.52 & 2.49 & 1.38 & 1.07 \\
\hline \multirow[t]{3}{*}{$\mathrm{Fe}$} & Control & 52512.53 & 53867.54 & 54191.49 & 49091.45 & 54939.17 & 52883.53 & 42100.00 & 41175.00 \\
\hline & treated & & 52422.72 & 49625.50 & 49848.42 & 53497.11 & 51562.99 & 40716.67 & 41866.67 \\
\hline & sd & & 907.29 & 938.85 & 871.35 & 1568.46 & 888.43 & 340.34 & 1936.71 \\
\hline \multirow[t]{3}{*}{$\mathrm{Mn}$} & Control & 783.00 & 815.00 & 780.00 & 707.00 & 812.00 & 784.00 & 760.00 & 704.50 \\
\hline & treated & & 761.75 & 702.00 & 695.00 & 712.00 & 666.50 & 581.33 & 670.00 \\
\hline & sd & & 23.25 & 9.17 & 3.00 & 35.59 & 60.72 & 7.77 & 33.29 \\
\hline \multirow[t]{3}{*}{$\mathrm{Pb}$} & Control & 37.30 & 30.60 & 28.50 & 43.50 & 46.20 & 35.50 & 39.00 & 38.00 \\
\hline & treated & & 30.53 & 39.10 & 42.35 & 38.23 & 37.38 & 40.50 & 41.00 \\
\hline & sd & & 0.38 & 8.61 & 2.45 & 4.58 & 2.83 & 2.60 & 3.46 \\
\hline \multirow[t]{3}{*}{$\mathrm{Zn}$} & Control & 77.49 & 78.08 & 78.40 & 72.67 & 79.57 & 76.54 & 77.00 & 76.00 \\
\hline & treated & & 77.34 & 74.52 & 75.11 & 79.77 & 76.27 & 77.58 & 88.32 \\
\hline & sd & & 2.70 & 3.26 & 2.33 & 3.45 & 0.72 & 1.66 & 4.35 \\
\hline
\end{tabular}


Table 4. Concentration of dissolved metals $\left(\mathrm{mg} . \mathrm{L}^{-1}\right)$ in samples of water column.

\begin{tabular}{|c|c|c|c|c|c|c|c|c|c|}
\hline \multirow{2}{*}{ Metal } & \multirow{2}{*}{ Microcosm } & \multicolumn{8}{|c|}{ Incubation time (days) } \\
\hline & & Initial & $\mathbf{t}=\mathbf{0}$ & $\mathbf{t}=\mathbf{5}$ & $t=10$ & $t=25$ & $\mathbf{t}=\mathbf{5 0}$ & $t=85$ & $\mathrm{t}=\mathbf{1 3 5}$ \\
\hline \multirow[t]{3}{*}{$\mathrm{Al}$} & Control & $<0.10$ & $<0.10$ & $<0.10$ & $<0.10$ & $<0.10$ & $<0.10$ & $<0.10$ & $<0.10$ \\
\hline & treated & & $<0.10$ & $<0.10$ & $<0.10$ & $<0.10$ & 0.130 & $<0.10$ & $<0.10$ \\
\hline & sd & & - & - & - & - & 0.042 & - & - \\
\hline \multirow[t]{2}{*}{$\mathrm{Cu}$} & Control & $<0.004$ & $<0.004$ & $<0.004$ & $<0.004$ & $<0.004$ & $<0.004$ & $<0.004$ & $<0.004$ \\
\hline & treated & & $<0.004$ & $<0.004$ & $<0.004$ & $<0.004$ & $<0.004$ & $<0.004$ & $<0.004$ \\
\hline \multirow[t]{3}{*}{$\mathrm{Ni}$} & Control & 0.007 & 0.008 & $<0.005$ & $<0.005$ & 0.013 & 0.025 & 0.030 & 0.021 \\
\hline & treated & & $<0.005$ & $<0.005$ & $<0.005$ & 0.008 & 0.010 & 0.016 & 0.015 \\
\hline & sd & & & & & 0.002 & 0.005 & 0.003 & 0.002 \\
\hline \multirow[t]{3}{*}{$\mathrm{Fe}$} & Control & $<0.05$ & $<0.05$ & $<0.05$ & $<0.05$ & $<0.05$ & $<0.05$ & $<0.05$ & $<0.05$ \\
\hline & treated & & $<0.05$ & 0.510 & 5.380 & 3.800 & 1.267 & $<0.05$ & $<0.05$ \\
\hline & $\mathrm{sd}$ & & - & 0.090 & 0.209 & 0.265 & 0.058 & - & - \\
\hline \multirow[t]{3}{*}{$\mathrm{Mn}$} & Control & $<0.02$ & 0.380 & 0.660 & 1.620 & 2.520 & 1.530 & $<0.02$ & 0.650 \\
\hline & treated & & 0.747 & 3.180 & 4.853 & 7.947 & 9.387 & 9.170 & 10.143 \\
\hline & $\mathrm{sd}$ & & 0.102 & 0.207 & 0.186 & 0.658 & 0.417 & 0.075 & 0.545 \\
\hline \multirow[t]{3}{*}{$\mathrm{Pb}$} & Control & 0.008 & 0.005 & 0.001 & $<0.001$ & $<0.001$ & 0.003 & $<0.001$ & $<0.001$ \\
\hline & treated & & $<0.001$ & $<0.001$ & $<0.001$ & $<0.001$ & 0.008 & $<0.001$ & $<0.001$ \\
\hline & $\mathrm{sd}$ & & - & - & - & - & 0.012 & - & - \\
\hline \multirow[t]{2}{*}{$\mathrm{Zn}$} & Control & $<0.02$ & $<0.02$ & $<0.02$ & 0.020 & $<0.02$ & $<0.02$ & $<0.02$ & $<0.02$ \\
\hline & treated & & $<0.02$ & $<0.02$ & $<0.02$ & $<0.02$ & $<0.02$ & $<0.02$ & $<0.02$ \\
\hline
\end{tabular}

Table 5. Concentration of dissolved metals $\left(\mathrm{mg} \cdot \mathrm{L}^{-1}\right)$ in samples of sediment pore water.

\begin{tabular}{|c|c|c|c|c|c|c|c|c|c|}
\hline \multirow{2}{*}{ Metal } & \multirow{2}{*}{ Microcosm } & \multicolumn{8}{|c|}{ Incubation time (days) } \\
\hline & & Initial & $\mathbf{t}=\mathbf{0}$ & $\mathbf{t}=\mathbf{5}$ & $t=10$ & $t=25$ & $\mathbf{t}=\mathbf{5 0}$ & $\mathrm{t}=\mathbf{8 5}$ & $\mathrm{t}=\mathbf{1 3 5}$ \\
\hline \multirow[t]{3}{*}{$\mathrm{Al}$} & Control & $<0.10$ & $<0.10$ & $<0.10$ & $<0.10$ & $<0.10$ & $<0.10$ & 0.480 & $<0.10$ \\
\hline & treated & & $<0.10$ & 0.390 & 0.197 & $<0.10$ & 0.213 & $<0.10$ & $<0.10$ \\
\hline & sd & & - & 0.434 & 0.134 & - & 0.123 & - & - \\
\hline \multirow[t]{2}{*}{$\mathrm{Cu}$} & Control & $<0.004$ & 0.006 & 0.018 & 0.008 & $<0.004$ & $<0.004$ & $<0.004$ & 0.006 \\
\hline & treated & & $<0.004$ & $<0.004$ & $<0.004$ & $<0.004$ & $<0.004$ & $<0.004$ & $<0.004$ \\
\hline \multirow[t]{3}{*}{$\mathrm{Ni}$} & Control & $<0.005$ & $<0.005$ & $<0.005$ & $<0.005$ & 0.008 & $<0.005$ & 0.010 & 0.012 \\
\hline & treated & & 0.009 & 0.012 & 0.011 & 0.015 & 0.010 & 0.021 & 0.033 \\
\hline & $\mathrm{sd}$ & & 0.001 & 0.003 & 0.001 & 0.007 & 0.001 & 0.012 & 0.013 \\
\hline \multirow[t]{3}{*}{$\mathrm{Fe}$} & Control & 0.140 & 0.800 & 1.410 & 3.370 & 9.400 & $<0.05$ & 0.870 & 0.150 \\
\hline & treated & & 100.300 & 37.700 & 46.833 & 13.067 & 2.367 & 1.903 & $<0.05$ \\
\hline & sd & & 8.676 & 3.306 & 1.320 & 10.302 & 0.493 & 0.497 & - \\
\hline \multirow[t]{3}{*}{$\mathrm{Mn}$} & Control & 7.900 & 7.310 & 6.840 & 6.450 & 14.900 & 3.080 & 4.200 & 4.730 \\
\hline & treated & & 41.533 & 34.367 & 30.767 & 13.267 & 13.167 & 11.833 & 12.900 \\
\hline & $\mathrm{sd}$ & & 0.306 & 1.716 & 0.404 & 7.984 & 2.250 & 1.185 & 3.466 \\
\hline \multirow[t]{3}{*}{$\mathrm{Pb}$} & Control & 0.002 & $<0.001$ & 0.002 & 0.003 & 0.006 & 0.008 & $<0.001$ & $<0.001$ \\
\hline & treated & & 0.004 & 0.004 & 0.004 & 0.004 & 0.004 & $<0.001$ & $<0.001$ \\
\hline & sd & & 0.003 & 0.002 & 0.001 & 0.001 & 0.001 & - & - \\
\hline \multirow[t]{3}{*}{$\mathrm{Zn}$} & Control & 0.043 & 0.036 & 0.022 & $<0.02$ & 0.027 & 0.026 & $<0.02$ & $<0.02$ \\
\hline & treated & & 0.049 & $<0.02$ & $<0.02$ & 0.032 & 0.039 & $<0.02$ & $<0.02$ \\
\hline & sd & & 0.011 & - & - & 0.005 & 0.010 & - & - \\
\hline
\end{tabular}


at all incubation times in samples of treated microcosm when compared to control microcosms, but the HAC did not indicate differentiation between treated and control microcosm groups, which is the opposite trend from that shown by iron and manganese.

These data are related to the AVS concentration, which showed a clearly visible decrease over time in the treated microcosm sediments. The AVS concentration reached a reduction of $99 \%$ in $t=135$ days in treated microcosm $\left(68.9 \mathrm{mg} . \mathrm{g}^{-1}\right)$ relative to the control microcosm $\left(5,072.8 \mathrm{mg} \cdot \mathrm{g}^{-1}\right)$, as shown in Figure 3. Evidence that nitrate acted as an effective electron acceptor was once more confirmed by the data obtained for sediment AVS and sulfate concentrations in sediment pore water and water column. The decrease in AVS with incubation time was followed by a progressive increase of sulfate concentrations in samples from water column and sediment pore water. The addition of nitrate to sediments enhances the sulfide oxidation rate, as expressed by the reaction $\mathrm{S}^{-2}+\mathrm{a}\left(\mathrm{NO}_{3}\right)_{2} \rightarrow \mathrm{CaSO}_{4}+\mathrm{N}_{2}$ (Babin et al. 2003). As a result, sulfide oxidation increased

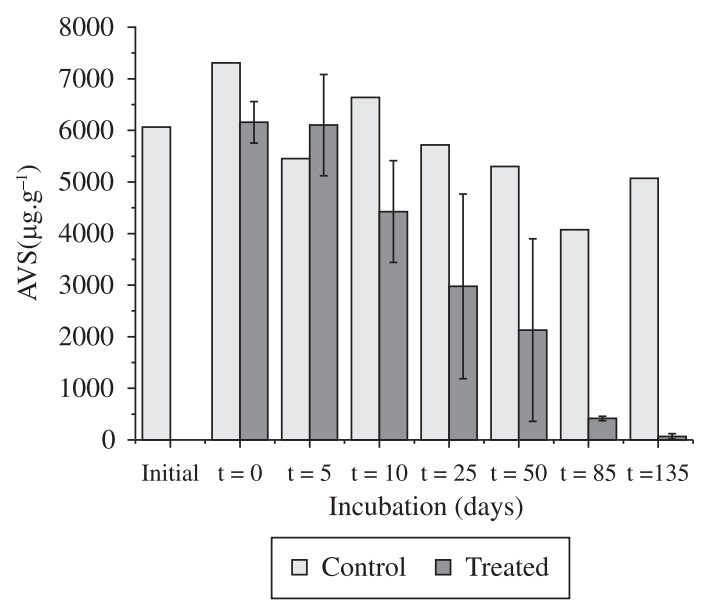

Figure 3. Acid volatile sulfide (AVS) concentration $\left(\mu \mathrm{g} \cdot \mathrm{g}^{-1}\right)$ in sediment samples at each incubation treatment time.

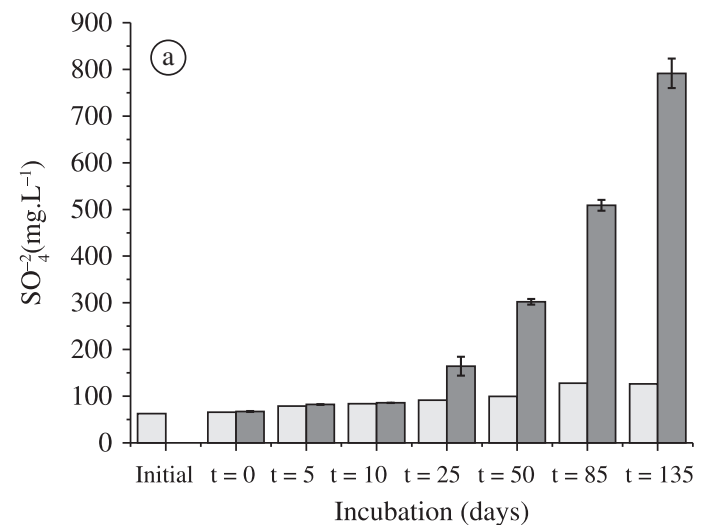

$\square$ Control $\square$ Treated the concentration of sulfate and the availability of iron and manganese, previously complexed as FeS and $\mathrm{MnS}$, which are the predominant forms of AVS. The sulfate concentration in the water column samples of treated microcosms ranged from $67.22 \mathrm{mg} . \mathrm{L}^{-1}$ in $\mathrm{t}=0$ day to $791.40 \mathrm{mg} . \mathrm{L}^{-1}$ in $\mathrm{t}=135$ days. In pore water samples, concentrations ranged from $125.78 \mathrm{mg} . \mathrm{L}^{-1}$ at $\mathrm{t}=0$ day to $1,539.31 \mathrm{mg} . \mathrm{L}^{-1}$ at $\mathrm{t}=135$ days. The sulfate concentrations are depicted in the graph in Figure 4.

With regard to toxicity, Soucek and Kennedy (2005) found 48 hours LC50 values for C. dubia of 1,869 and $4,220 \mathrm{mg} \mathrm{SO}_{4}^{-2} \mathrm{~L}^{-1}$ for low and high hardness, respectively, in tested samples. These values are above the maximum value found in the present work in sediment pore water samples of treated microcosms $\left(1,539.3 \mathrm{mg} \mathrm{SO}_{4}^{-2} \mathrm{~L}^{-1}\right)$. With regard to manganese, it is known that the 48 hours LC50 for $C$. dubia reported in the literature varies from 12.7 to $20 \mathrm{mg} \mathrm{Mn} \mathrm{L}^{-1}$ (15 mg Mn L $\mathrm{mg}^{-1}$ - Lasier et al., 2000; 17 to $20 \mathrm{mg} \mathrm{Mn} \mathrm{L}^{-1}$ - Hockett and Mount, 1996; and $12.7 \mathrm{mg} \mathrm{Mn} \mathrm{L}^{-1}$ - Stubblefield et al., 1997 apud Lasier et al., 2000). The Mn concentrations found in this work in sediment pore water samples of the treated microcosms were higher than the existing LC50 data. However, these concentrations decreased with incubation time, reaching $12.9 \mathrm{mg} \mathrm{Mn} \mathrm{L}^{-1}$ at $\mathrm{t}=135$ days. The $\mathrm{Mn}$ concentrations were lower than 48 hours LC50 in water column samples, increasing over incubation time and reaching $10.14 \mathrm{mg} \mathrm{Mn} \mathrm{L}^{-1}$ in $\mathrm{t}=135$ days (Table 4 ).

The absence of toxicity to $C$. silvestrii caused by metals may be assessed by the results obtained from $\mathrm{SEM} \mathrm{Cd}, \mathrm{Cu}, \mathrm{Ni}, \mathrm{Pb}$ and $\mathrm{Zn}$. The SEM concentrations obtained for samples of treated microcosms were lower than those of control microcosms (Figure 5), but increased with incubation time and exceeded those of the control microcosms at $\mathrm{t}=145$ days. This would imply that some of the SEM may be toxic to the benthic organisms, since the AVS that control toxicity in sediments were very low at this time (Figure 3). However, analysing the difference [SEM] - [AVS] suggested by USEPA (2000), there was no

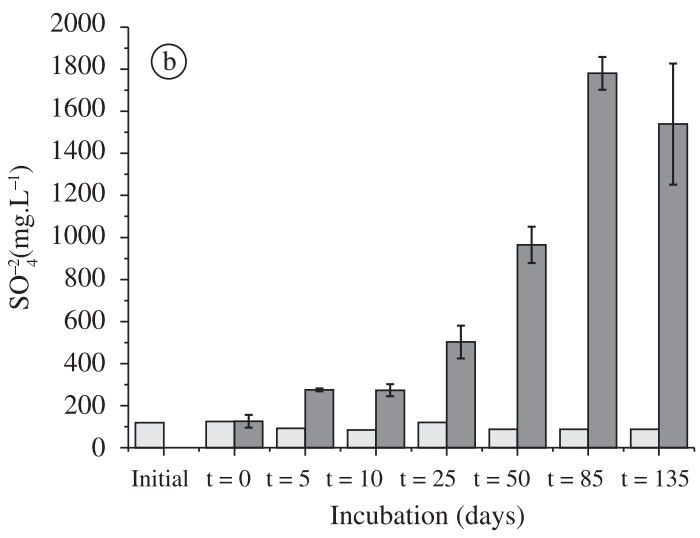

Figure 4. Sulfate $\left(\mathrm{SO}_{4}^{-2}\right)$ concentrations in: a) water column, b) sediment pore water. 


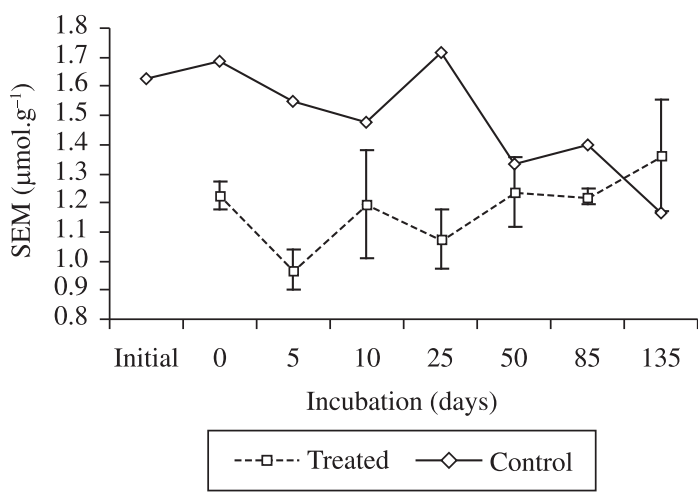

Figure 5. Sum of simultaneously extracted metal concentration (SEM) $\left(\mu \mathrm{mol} . \mathrm{g}^{-1}\right)$ of sediment samples at each incubation treatment time.

excess of metals in relation to the AVS ([SEM]- $[\mathrm{AVS}]<0)$. Therefore, toxicity is not expected to increase as a result of SEM in a period of more than 135 days.

\section{Conclusions}

Risks associated with treatment through the addition of nitrate to sediments became evident from the chemical ecotoxicological data obtained in this work. Although the toxicity of sediment pore water samples from treated microcosms to $C$. silvestrii did not decrease in $\mathrm{t}=85$ days, our results indicated a tendency for this toxicity to diminish the from treatment time of $\mathrm{t}=85$ days to $\mathrm{t}=135$ days. Moreover, adverse effects caused to organisms in the water column can be reduced over time after nitrate application.

Toxicity tests with Ibirité reservoir sediments showed that treated sediments were harmful to test organisms up to 85 days after nitrate application. The decrease in toxicity to $C$. xanthus at $\mathrm{t}=135$ days allows us to postulate that treated sediments may recover their capacity to nurture a normal benthic community. This finding corroborates the findings of Ripl (1976), who reported that, after recovering from the application of nitrate, sediments can regain their ability to support benthic macrofauna. However, we believe that, from the ecotoxicological point of view, the recovery of sediments would be better evaluated if chronic toxicity assays were performed, since they provide endpoints such as development and growth, which are more sensitive indicators than mere survival.

Another aspect to be considered is the efficiency of $\mathrm{P}$ retention capacity in sediments, which was the main target of this study. Based on experiments similar to ours, Yamada (2010) reported an average orthophosphate ion retention capacity in the order of $61 \%$ in control microcosms in $\mathrm{t}=50$ days. However, these preliminary experiments showed, at $\mathrm{t}=145$ days, an unexpected lower retention efficiency of only $47 \%$. For sediment pore water, Yamada (2010) obtained a difference of 32 and 36\% in orthophosphate concentrations in the samples of treated microcosm compared to control microcosms, in $\mathrm{t}=50$ and $t=135$ days, respectively. These experiments are currently being repeated, aiming at a higher $\mathrm{P}$ retention capacity in sediments.

The data presented in this work demonstrated that the implementation of a sediment treatment programme for the Ibirite reservoir involving the addition of calcium nitrate may be viable if longer incubation times are considered. However, such a programme should be implemented only after a detailed and systematic study of the impact on the aquatic fauna in situ and on the phosphorus retention efficiency in sediments. The results of the present study may serve to underpin ongoing in situ studies.

Acknowledgements - We would like to thank FAPESP (no.07/52972-5) for the M.Sc. scholarship granted to the first author, and REGAP-CENPES/Petrobras (Brazil) for its financial support of this project.

\section{References}

ALLEN, HE., FU, G. and DENG, B., 1993. Analysis of acidvolatile sulfide (AVS) and simultaneously extracted metals (SEM) for estimation of potencial toxicity inaquatic sediments. Environmental Toxicology and Chemistry, vol. 12, p. 14-41.

ANDERSEN, HB. and BUCKLEY, JA., 1998. Acute toxicity of ammonia to Ceriodaphnia dubia and a procedure to improve control survival. Bulletin of Environmental Contamination and Toxicology, vol. 61, p. 116-122. PMid:9657839. http://dx.doi. org/10.1007/s001289900737

American Public Health Association - APHA, 1992. Standard methods: for examination of water and wastewater. 18nd ed. Washington: APHA.

Associação Brasileira de Normas Técnicas - ABNT, 2004. NBR 12713: Ecotoxicologia Aquática - Toxicidade aguda Método de ensaio com Daphnia spp. (Cladocera, Crustacea). Rio de Janeiro: ABNT.

BABIN, J., KAU, P. and CHAN, L., 2003. In situ sediment treatment to control odours and enhance biological breakdown of organic matter in Shing Mun River, the Hong Kong special administration region. In Proceedings of the 2nd International Symposium on Contaminated Sediments, 2003. Quebec City, Canada.

BARBOSA, FAR. 2003. Projeto Ibirité. Padrões de estratificação térmica/química e suas implicações para a estrutura da comunidade bentônica, qualidade da água e conservação da Represa de Ibirité - REGAP/Petrobrás, MG. Universidade Federal de Minas Gerais (UFMG), Belo Hoizonte, MG.

BURTON JUNIOR, GA., 2002. Sediment quality criteria in use around the world. Limnology, vol. 3, p. 65-75.

CAMARGO, JA. and ALONSO, A., 2006. Ecological and toxicological effects of inorganic nitrogen pollution in aquatic ecosystems: A global assessment. Environmental International, vol. 32, p. 831-849. PMid:16781774. http://dx.doi.org/10.1016/j. envint.2006.05.002

Camargo, JA., Alonso, A. and Salamanca, A., 2005. Nitrate toxicity to aquatic animals: a review for freshwater invertebrates. Chemosphere, vol. 58, p. 1255-1267. PMid:15667845. http:// dx.doi.org/10.1016/j.chemosphere.2004.10.044 
DI TORO, DM., MAHONY, JD., HANSEN, DJ., SCOTT, KJ., HICKS, MB., MAYR, SM. and REDMOND, MS., 1990. Toxicity of cadmium in sediments: the role of acid volatile sulfide. Environmental Toxicology and Chemistry, vol. 11, p. 1487-1502.

DORNFELD, CB., ESPÍNDOLA, ELG., FRACÁCIO, R., RODRIGUES, BK. and NOVELLI, A. 2006. Comparação de bioensaios laboratoriais e "in situ" utilizando Chironomus xanthus na avaliação da toxicidade de sedimentos do Rio Monjolinho (São Carlos, SP). Journal of the Brazilian Society of Ecotoxicology, vol. 1, no. 2, p. 161-165. http://dx.doi.org/10.5132/jbse.2006.02.014

FEIBICKE, M., 1997. Impact of nitrate addition on phosphorous availability in sediment and water column on plankton biomass experimental field study in shallow brackish Schlei Fjord (Western Baltic, Germany). Water, Air, \& Soil Pollution, vol. 99, p. 445-456. http://dx.doi.org/10.1007/BF02406884

FONSECA, AL., 1997. Avaliação da qualidade de água na bacia do Rio Piracicaba/SP através de testes de toxicidade com invertebrados. São Carlos: Escola de Engenharia de São Carlos, Universidade de São Paulo. Tese de Doutorado em Hidráulica e Saneamento.

FONSECA, AL. and ROCHA, O., 2004a. The life-cycle of Ceriodaphnia silvestrii Daday, 1902, a neotropical endemic species (Crustacea, Cladocera, Daphnidae). Acta Limnologica Brasiliensia, vol.16, no. 4, p. 319-328.

-, 2004b. Laboratory cultures of the native species Chironomus xanthus Rempel, 1939 (Diptera-Chironomidae). Acta Limnologica Brasiliensia, v. 16, no. 2, p.153-161.

FOY, RH., 1986. Suppression of phosphorous release from lake sediments by the addition of nitrate. Water Research, vol. 20, no. 11 , p. $1345-1351$.

HAMILTON, MA., RUSSO, RC. and THURSTN, RV., 1977. Trimmed Spearman-Karber method for estimating median lethal concentration in toxicity bioassays. Environmental Science \& Technology, vol. 11, p. 714-719. Corretion (1978), vol. 12, p. 417.

HOCKETT, JR. and MOUNT, DR., 1996. use of metal chelating agents to differentiate among sources of acute aquatic toxicity. Environmental Toxicology and Chemistry, vol. 15, p. 1687-1693.

LASIER, PJ., WINGER, PV. and BOGENRIEDER, KJ., 2000. Toxicity of manganese to Ceriodaphnia dubia and Hyalella azteca. Archives of Environmental Contamination and Toxicology, vol. 38, p. 298-304. PMid:10667926. http://dx.doi.org/10.1007/ s002449910039

MADIGAN, MT. and MARTINKO, JM., 2006. Brockbiology of microorganisms. 11nd ed. New York: Person Education Inc. 992 p.

MARSDEN, MW., 1989. Lake restoration by reducing external phosphorus loading: the influence of sediment phosphorus release. Freshwater Biology, vol. 21, p. 139-162. http://dx.doi. org/10.1111/j.1365-2427.1989.tb01355.x

MCAULIFFE, TF., LUKATELICH, RJ., MCCOMB, AJ. and QIU, S., 1998. Nitrate applications to control phosphorous release from sediments of a shallow eutrophic estuary: an experimental evaluation. Marine \& Freshwater Research, vol. 49, p. 463-473. http://dx.doi.org/10.1071/MF97116

MOZETO, AA., 2003. Projeto Ibirité. São Carlos: Laboratório de Biogeoquímica Ambiental, UFSCar. 116 p. Relatório, no. 6. Relatório Final. Parte I: Biodisponibioidade e toxicidade de contaminantes da represa do Ibirité. Parte II: Origem e geocronologia de sedimentos da represa do Ibirité (MG).
-, 2008. Projeto Ibirité, Fase II - Confirmação de Diagnóstico Ambiental da Represa Ibirité Laboratório de Biogeoquímica Ambiental. São Carlos: Laboratório de Biogeoquímica Ambiental, UFSCar. 87 p. Relatório no. 2.

Mozeto, AA., Montini, M., Braz, SA., Martins, FG., Soares, A., Nascimento, MRL., Barbosa, FAR., Faria, BM. 2010. Biogeochemical assessment of the Ibirité Reservoir and its tributaries (MG-Southeastern Brazil). Part III: External versus internal loadings of nutrients and their implications to water quality. $20 \mathrm{p}$.

MURPHY, T. MOLLER, A. and BROUWER, H. 1995. In situ treatment of Hamilton Harbour sediment. Journal of the Aquatic Ecosystem Health and Management Society, vol. 4, p. 195-203. http://dx.doi.org/10.1007/BF00116654

Nascimento, MRL., Mozeto, AA. 2008. Reference values for metals and metalloids concentrations in bottom sediments of Tiete River basin, Southeast of Brazil. Soil \& Sediment Contamination, v. 17, n.3, p. 269 - 278. http://dx.doi.org/10.1080/15320380802006996

Oliveira-Neto, AL. and Botta-Paschoal, CMR. 2000. Sensibilidade do cladocera lacustre planctônico Ceriodaphnia silvestrii (Família Daphnidae) aos metais cádmio, cromo e chumbo. In ESPÍNDOLA, ELG., BOTTA-PASCHOAL, CMR., ROCHA, O., BOHRER, MBC. and OLIVEIRA-NETO, AL. (Eds). Ecotoxicologia - Perspectivas para o século XXI. São Carlos: Rima Editora. p. 537-543.

PETZOLDT, T. and UHLMANN, D. 2006. Nitrogen emissions into freshwater ecosystems: is there a need for nitrate elimination in all wastewater treatment plants? Acta Hydrochimica et Hydrobiologica, vol. 34, p. 305-324. http://dx.doi.org/10.1002/aheh.200500638

RAND, GM. and PETROCELLI, SR. 1985. Fundamentals of aquatic toxicology. Washington: Hemisphere. 665 p.

RIPL, W., 1976. Biochemical oxidation of polluted lake sediment with nitrate - A new lake restoration method. Ambio, vol. 5, no. 3, p. 132-135.

SANTOS, MAPF., VICENSOTTI, J. and MONTEIRO, RTR. 2007. Sensitivity of four test organisms (Chironomus xanthus, Daphnia magna, Hydra attenuata and Pseudokirchneriella subcapitata) to $\mathrm{NaCl}$ : an alternative reference toxicant. Journal of the Brazilian Society of Ecotoxicology, vol. 2, no. 3, p. 229-236. http://dx.doi. org/10.5132/jbse.2007.03.004

SCHAUSER, I., CHORUS, I. and LEWANDOWSKI, J., 2006. Effects of nitrate on phosphorus release: comparison of two Berlin lakes. Acta Hydrochimica et Hydrobiologica, vol. 34, p. 325-332. http://dx.doi.org/10.1002/aheh.200500632

SCOTT, G. and CRUNKILTON, RL., 2000. Acute and chronic toxicity of nitrate to fathead minnows (Pimephales promelas), Ceriodaphnia dubia and Daphnia magna. Environmental Toxicology and Chemistry, vol. 19, p. 2918-2922.

Silvério, PF., Nascimento, MRL., Mozeto, AA. 2006. Valores-guia de qualidade de sedimentos de ambientes aquáticos continentais e valores de referência de metais e metalóides. In MOZETO, AA., UMBUZEIRO, GA. and JARDIM, WF. (Eds). Métodos de coleta, análises físico-químicas e ensaios biológicos e ecotoxicológicos de sedimentos de água doce. São Carlos: Cubo Multimidia. p. 70-89.

Sotero-Santos, RB., Rocha, O. and Povinelli, J. 2007. Toxicity of ferric chloride sludge to aquatic organisms. Chemosphere, vol. 68 , p. 628-636.

SOUCEK, DJ. and KENNEDY, J., 2005. Effects of hardness, chloride, and acclimation on the acute toxicity of sulfate to freshwater 
inverstebrates. Environmental Toxicology and Chemistry, vol. 24, p. 1204-1210. http://dx.doi.org/10.1897/04-142.1

STUMM, W. and MORGAN, JJ., 1996. Aquatic Chemistry. 3nd ed. New York: Wiley-Interscience. 1022 p.

TAKENAKA, RA., DELLAMANO-OLIVEIRA, MJ. and ROCHA, O. 2007. Toxicidade de Extratos de Florações de Cianobactérias de Reservatórios do Rio Tietê, SP, aos dafinídeos Ceriodaphnia dubia e Ceriodaphnia silvestrii (Cladocera, Crustacea). Journal of the Brazilian Society of Ecotoxicology, vol. 2, no. 2, p. 147156. http://dx.doi.org/10.5132/jbse.2007.02.007

TRIVINHO-STRIXINO, S., and STRIXINO, G., 1982. Ciclo de vida de Chironomus sancticaroli Strixino; Strixino (Diptera, Chironomidae). Revista Brasileira Entomologia, vol. 26, no. 2, p. $183-189$.

TUNDISI, JG., Matsumura-Tundisi, T. and Tundisi, JEM., 2008. Reservoirs and human well being: new challenges for evaluating impacts and benefits in the neotropics. Brazilian Journal of Biology, vol. 68, no. 4 suppl., p. 1133-1135. http://dx.doi.org/10.1590/ S1519-69842008000500020
United Sates Environmental Protection Agency - USEPA, 1996. Acid Digestion of Sediments, Sludges and soil - Method 3050B. Washington: USEPA.

-, 1999. Update of ambient water quality criteria for ammonia. (EPA/822/R-99-014). Washington: USEPA.

-, 2000. Equilibrium partitioning sediments guidelines (ESGs) for the protection of benthic organisms: metal mixtures (cadmium, copper, lead, nickel, silver and zinc). (EPA/822/R00/005). Washington: USEPA.

VACCARI, DA., STROM, PF. and ALLEMAN, JE., 2006. Environmental Biology for Engineers and Scientists. New York: Wiley-Interscience. $931 \mathrm{p}$.

VAN RIJN, JAAP, TAL, Y. and SCHREIER, HJ, 2006. Denitrification in recirculating systems: Theory and applications. Aquac. Engineering, vol. 34, p. 364-376. http://dx.doi.org/10.1016/j. aquaeng.2005.04.004

YAMADA, TM., 2010. Remediação de sedimentos eutróficos da Represa Ibirité (MG) pela adição de nitrato de Phoslock TM: experimentos em laboratório. São Carlos: Universidade Federal de São Carlos. Tese de Doutorado. 